\title{
PERKIRAAN PADAT PENEBARAN IKAN KERAPU MACAN (Epinephelus fuscoguttatus) YANG OPTIMUM BERDASARKAN PADA KEBUTUHAN OKSIGEN TERLARUT
}

\author{
Arif Dwi Santoso")
}

\begin{abstract}
ABSTRAK
Studi tentang perkiraan padat penebaran optimum pada ikan kerapu macan (Epinephelus fuscoguttatus) berdasarkan pada kebutuhan oksigen terlarut telah dilakukan pada areal Teluk Hurun, Lampung pada bulan Juli 2003. Rata-rata hasil pengukuran kualitas lingkungan keramba jaring apung $13,5 \mathrm{~m}^{3}$ yang berisi ikan kerapu macan meliputi oksigen terlarut 3,68-6,76 $(5,35 \pm 0,25) \mathrm{mg} / \mathrm{L}$ suhu air 28,64-29,72 $(29,09 \pm 0,09)$ ${ }^{\circ} \mathrm{C}$. Salinitas $32,69-33,0(32,94 \pm 0,13)$ psu and turbiditas $0,27-13,62(1,15 \pm 0,41)$ NTU. Data tambahan meliputi laju pemasukan air sungai sekitar $0,02 \mathrm{~m}^{3} /$ detik dan kecepatan arus $2,3-5,1 \mathrm{~cm} /$ detik. Dari analisis data laju respirasi ikan kerapu macan yang diukur dengan mengunakan fish chamber menghasilkan fungsi korelasi terhadap bobot badan ikan yaitu $Y=0,0038+0,6108$ dengan $R^{2}=0,7437$ dan fungsi padat penebaran yang optimum yaitu $Y=1505,6 \times X^{-0.632} ; R^{2}=0,7419$. Dari kedua fungsi tersebut didapatkan rekomendasi penentuan padat penebaran yang optimum berdasarkan kebutuhan oksigen terlarut dengan batasan sebagai berikut: stok ikan berukuran kurang dari $50 \mathrm{~g}$ disarankan ditebar dengan kepadatan $175 \mathrm{ekor} / \mathrm{m}^{3}$, ikan ukuran 100--200 g sekitar 63 ekor $/ \mathrm{m}^{3}$ dan ikan ukuran lebih dari $1.200 \mathrm{~g}$ sekitar 17 ekor/m .
\end{abstract}

ABSTRACT: Study on the optimum stocking rate estimation on tiger grouper (Epinephelus fuscoguttatus) base on dissolved oxygen budged. By: Arif Dwi Santoso

Study on the optimum stocking rate estimation on tiger grouper (Epinephelus fuscoguttatus) base on dissolved oxygen budged was held in aquaculture area Hurun Bay Lampung in July 2003. Environmental parameters of Hurun Bay estuary were monitored at the site of $13.5 \mathrm{~m}^{3}$ floating net cages for $E$. fuscoguttatus in July 2003. Average dissolved oxygen inside cages was 3.68-6.76 (5.35 \pm 0.25$) \mathrm{mg} / \mathrm{L}$ with water temperature 28.64-29.72 (29.09 \pm 0.09$){ }^{\circ} \mathrm{C}$. Salinity 32.69-33.0 (32.94 \pm $0.13)$ psu and turbidity 0.27-13.62 (1.15 \pm 0.41$)$ NTU. Inflow rate of cages was 0.02 $\mathrm{m}^{3} / \mathrm{sec}$ with current velocity $2.3-5.1 \mathrm{~cm} / \mathrm{s}$. Results showed that the functions of respiration rate for correlation between respiration of $E$. fucoguttatus and their weight was $Y=0.0038 x+0.6108$ with $R^{2}=0.7437$ meanwhile the functions of optimum stocking density was $Y=1505.6 X^{-0.632}, R^{2}=0.7419$. On basis of dissolved oxygen budged, estimated optimum stocking density for lower limit was $175 \mathrm{ind} . / \mathrm{m}^{3}$ for fish $50 \mathrm{~g}$ in average, 63 ind. $/ \mathrm{m}^{3}$ for fish $100--200 \mathrm{~g}$ and 17 ind./m3 for fish up to 1,200 $\mathrm{g}$.

KEYWORDS: stocking rate, tiger grouper, DO budged, floating net cages, respiration

\footnotetext{
Peneliti pada Pusat Teknologi Lingkungan-BPPT, Jakarta
} 


\section{PENDAHULUAN}

Dalam sistem budi daya ikan di keramba jaring apung (KJA) atau dengan lainnya, penentuan padat penebaran (stocking rate) merupakan kegiatan yang sangat menentukan dalam menunjang keberhasilan usaha (Boyd, 1990; Fukuda et al., 1966; Kaspriyo et al., 2004). Penerapan padat penebaran yang tepat selain akan menimimasi kondisi lingkungan yang buruk juga akan memberi kesempatan yang cukup baik bagi biota dalam memanfaatkan pakan, oksigen dan ruang secara optimal sehingga pertumbuhan ikan berjalan secara optimal pula.

Fukuda et al. (1966) berhasil membuat model untuk memperkirakan padat penebaran ikan ekor kuning (Seriola quinquerradiata) di tambak berdasarkan perbedaan kualitas pasokan air masuk dan keluar tambak. Selain itu, juga menyarankan untuk menyempurnakan modelnya dengan memasukkan faktor perubahan oksigen terlarut. Keberhasilan Fukuda diteruskan oleh Inoue (1974) yang berhasil membuat sebuah model dengan memperhatikan kebutuhan oksigen terlarut bagi ikan yang akan diprediksi. Model tersebut menyatakan bahwa variabel oksigen terlarut adalah variabel yang penting dalam penentuan padat penebaran (Inoue, 1974).

Kandungan oksigen dalam air dan kebutuhan ikan pada oksigen terlarut adalah faktor yang penting untuk diketahui oleh pembudi daya ikan selain faktor lain seperti operasional kegiatan (Muawanah et al., 2003; Nabhitabhata et al., 2002). Kandungan oksigen dalam air merupakan faktor kritis bagi kesehatan ikan, pada awalnya ikan yang kekurangan oksigen akan mengalami stres fisik. Pada umumnya ikan memerlukan konsentrasi oksigen dalam air minimum $5 \mathrm{mg} /$ L (Boyd, 1990). Oksigen yang cukup akan mempercepat proses pertumbuhan, karena proses metabolisme sangat tergantung pada oksigen yang dikonsumsi oleh ikan tersebut. Penyakit akan timbul jika terjadi ketidakseimbangan lingkungan ekosistem yaitu interaksi antara ikan, pathogen, dan lingkungan (Boyd, 1990; Kaspriyo et al., 2004). Masing masing ikan mempunyai daya toleransi terhadap lingkungan yang berbeda antara satu spesies dengan spesies yang lain.

Tujuan dari penelitian ini adalah untuk mengetahui kebutuhan oksigen terlarut pada ikan kerapu macan yang optimal serta untuk menduga padat penebarannya (stocking rate) pada KJA.

\section{BAHAN DAN METODE}

Penelitian dilakukan pada tanggal 21--22 Juli 2003, terbagi dalam kegiatan laboratorium dan survai lapangan. Kegiatan laboratorium meliputi eksperimen respirasi ikan dan penentuan panjang-bobot ikan, sedangkan survai lapangan meliputi kegiatan pengukuran debit pemasukan air sungai ke teluk, kondisi hidrografi, dan kualitas air sekitar keramba.

\section{Kegiatan Laboratorium}

Eksperimen respirasi ikan dilakukan di Labolatorium Lingkungan dan Kesehatan Ikan Balai Budidaya Laut Lampung. Sebanyak 25 ekor ikan kerapu macan diukur laju respirasinya dengan mengunakan alat fish chamber (Gambar 1) (Santoso, 2005).

Fish chamber adalah rangkaian alat yang terdiri atas tabung transparan bervolume 49,6 $\mathrm{cm}^{3}$ yang dilengkapi dengan DO meter, thermometer, dan pompa air. Pintu tabung

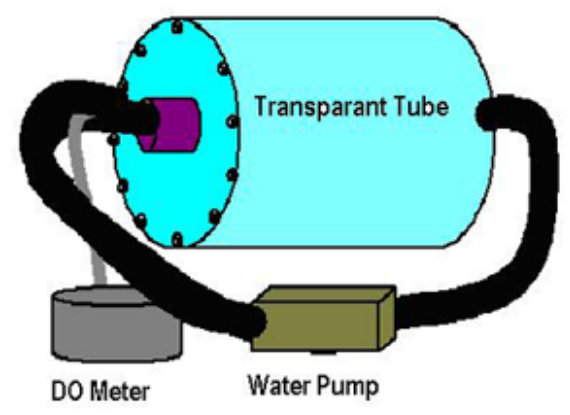

Gambar 1. Peralatan fish chamber 
transparan diatur sedemikian rupa sehingga memungkinkan ikan dapat dengan mudah masuk dan dapat ditutup dengan rapat kembali tanpa ada gelembung udara di dalam tabung. DO meter dan termometer diperlukan untuk mengukur perubahan oksigen terlarut dan temperatur air dalam tabung selama percobaan berlangsung. Sedangkan pompa berfungsi untuk mengaduk air dalam tabung sehingga konsentrasi air dalam tabung homogen.

Ikan kerapu yang akan digunakan sebagai bahan eksperimen sebelumnya dimasukkan dalam bak terbuka 3,3 $\mathrm{m}^{3}$ dengan aerator dan dibiarkan selama 20 menit untuk mengadaptasikan ikan pada lingkungan eksperimen. Di dalam bak yang sama, alat fish chamberyang terangkai dengan DO meter dan pompa air juga disiapkan. Setelah kondisi oksigen terlarut dan suhu air dalam bak terbuka stabil, satu persatu ikan kerapu dimasukkan kedalam alat fish chamber.

Setiap ikan eksperimen akan diukur laju respirasinya dengan membandingkan konsentrasi oksigen terlarut pada awal dan akhir eksperimen. Setelah tahap ini selesai, ikan kemudian diukur panjang dan bobot tubuhnya, tahap terakhir adalah mengukur volume ikan dengan memasukkan ikan dalam tabung volume.

\section{Kegiatan Survai}

Kegiatan survai lapangan dilakukan di sekitar KJA selama 25 jam. Kegiatan ini terdiri atas 3 kegiatan yang meliputi pengambilan data dengan chlorotec probe (Chlorotec, type AAQ1 183, Alec Electronics) setiap satu jam sekali, pengambilan data arus dan debit air sungai yang masuk ke Teluk Hurun dengan current meter serta data pendugaan produktivitas perairan dengan mengGunakan metode botol gelap-terang.

Data yang bisa diambil dari chlorotec probe meliputi data suhu air, salinitas, DO, turbiditas, $\mathrm{pH}$ dan Klorofil $a$. Data $\mathrm{pH}$ dan klorofil a tidak digunakan dalam penelitian ini. Data suhu air, salinitas, DO, turbiditas dan data lapangan lainnya kemudian diaplikasikan kedalam sebuah model Dissolved Oxygen Budged berdasar pada Inoue (1974) di bawah ini:

$$
\mathrm{R} * \mathrm{~N} / \mathrm{V}=\mathrm{Q} / \mathrm{V} *(\mathrm{DOr}-\mathrm{DOC})+\mathrm{Bw}
$$

di mana:

R : Konsumsi oksigen terlarut oleh ikan ( $\mathrm{mgO}_{2} /$ menit)

$\mathrm{N} \quad$ : Jumlah ikan di dalam KJA (ekor)
$\mathrm{V} \quad$ : Volume dari KJA $\left(\mathrm{m}^{3}\right)$

$\checkmark \quad$ : Kecepatan arus keluar-masuk KJA (m/ detik)

Q : Debit aliran keluar-masuk KJA ( $\mathrm{m}^{3} /$ detik)

Dor : Konsentrasi oksigen terlarut di luar KJA (mg/L)

Doc : Konsentrasi oksigen terlarut di dalam KJA (mg/L)

Bw : Konsumsi oksigen terlarut oleh badan air $\left(\mathrm{mgO}_{2} / \mathrm{L} / \mathrm{jam}\right)$, dari data metode gelapterang

Untuk mengetahui debit aliran air dalam $\mathrm{KJA}$, digunakan rumus sebagai berikut:

$$
\mathbf{Q}=\mathbf{N c} * \mathbf{v} * \mathbf{A}
$$

di mana:

$$
\begin{array}{ll}
\mathrm{Nc} & \text { : Koefisien dari aliran } \\
\mathrm{A} & \text { : Luasan } \mathrm{KJA}\left(\mathrm{m}^{2}\right) \\
\mathrm{V} & \text { : Kecepatan arus keluar-masuk KJA (m/detik) } \\
\mathrm{Q} & \text { : Debit aliran keluar-masuk KJA }\left(\mathrm{m}^{3} / \text { detik }\right)
\end{array}
$$$$
\mathrm{Nc}=\mathrm{Vr} / \mathrm{Vc}
$$

di mana:

$\mathrm{Vr}$ : Kecepatan arus di luar KJA (m/detik)

Vc : Kecepatan arus di dalam KJA (m/detik)

Kecepatan arus di dalam (Vc) dan di luar (Vr) KJA diukur dengan cara memasang 2 buah current meter pada kedalaman $2 \mathrm{~m}$ tepat di tengah KJA dan di luar KJA pada selama 48 jam. Data arus di atas kemudian dianalisis untuk mendapatkan data debit aliran air yang keluarmasuk KJA.

Aktual koefisien aliran (\%) adalah:

Aktual koef. aliran $(\%)=$ Nc $* 100 \ldots .(4)$

\section{HASIL DAN BAHASAN}

\section{Kondisi Kualitas Lingkungan}

Perubahan parameter di dalam keramba yang diamati selama eksperimen 25 jam meliputi kondisi oksigen terlarut, suhu, salinitas, turbiditas, laju pemasukan air sungai, dan kecepatan arus.

Konsentrasi rata-rata oksigen terlarut di dalam keramba adalah 5,35 $\pm 0,25 \mathrm{mg} / \mathrm{L}$, Ratarata salinitas $32,94 \pm 0,13$ psu, rata-rata suhu $29,09^{\circ} \mathrm{C} \pm 0,09^{\circ} \mathrm{C}$ dan rata rata turbiditas adalah $1,15 \pm 0,41$ NTU. Sementara data laju pemasukan air sungai sebesar $0,02 \mathrm{~m}^{3} /$ detik dan kecepatan arus sebesar 2,3-5, $1 \mathrm{~cm} /$ detik.

Kondisi oksigen terlarut, salinitas, dan suhu air dalam keramba selama eksperimen 25 jam ditunjukkan pada Gambar 2. Perubahan 

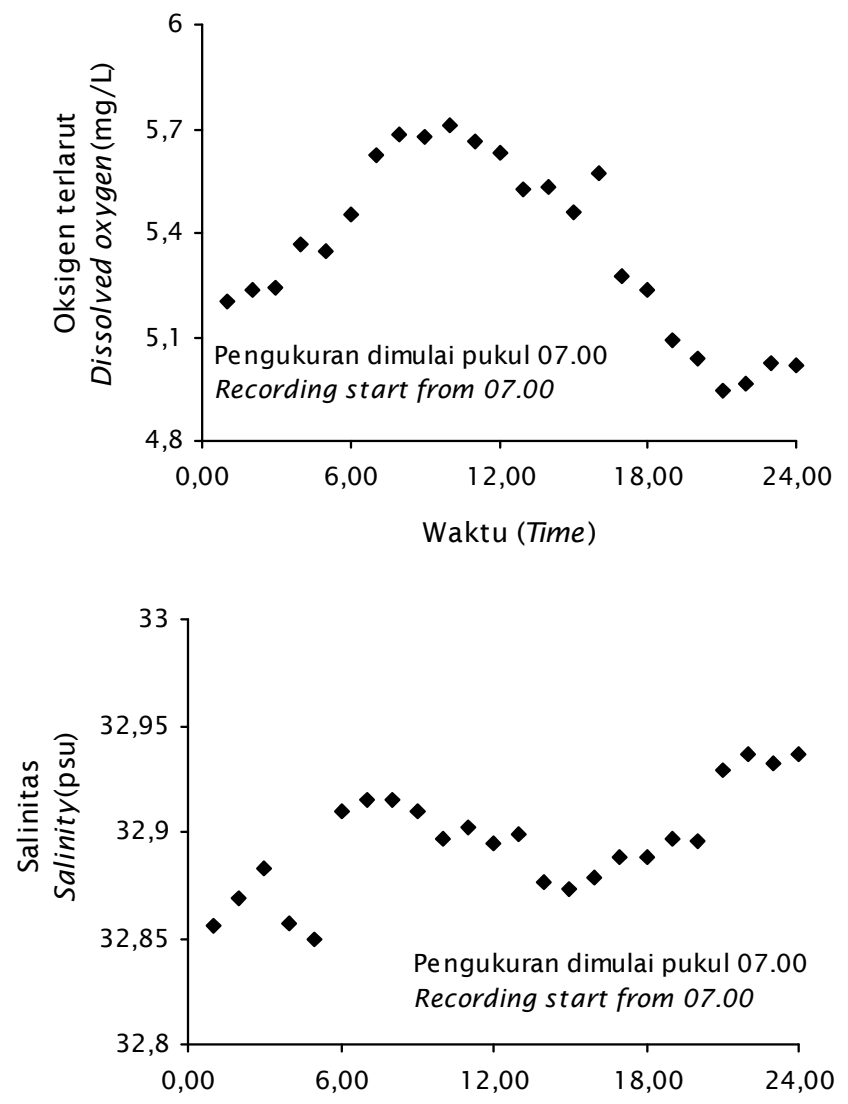

Waktu (Time)

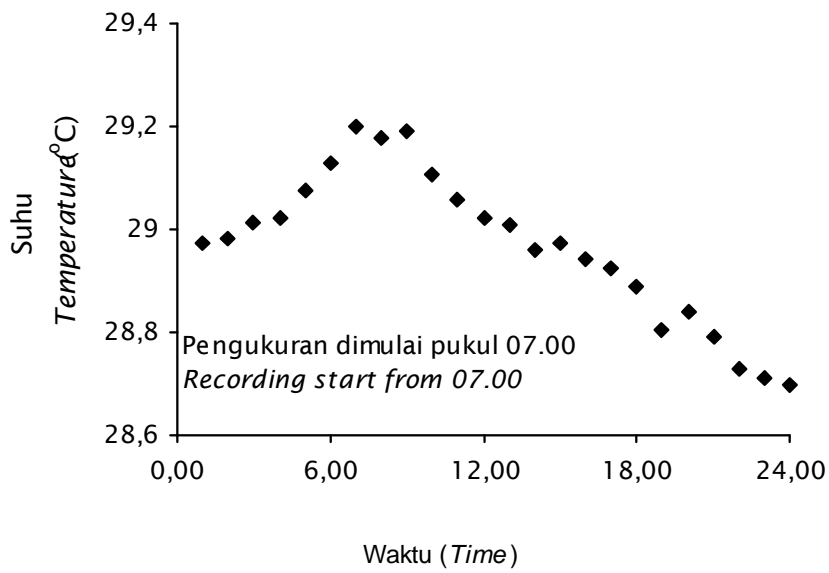

Gambar 2. Grafik hasil pengukuran kondisi oksigen terlarut (atas), salinitas (tengah), dan sahu perairan (bawah) selama survai 25 jam

Figure 2. Graphic of measured result for oxygen disolved (up), Salinity (mid), and temperatura (down) during 25 hours survey 
parameter oksigen terlarut dan suhu berlangsung alami sesuai perubahan harian parameter-parameter tersebut, yakni mengalami peningkatan maksimal sekitar pukul 14.00-15.00 dan kemudian berangsur-angsur turun seiring penurunan penyinaran matahari (Muawanah et al., 2003). Konsentrasi oksigen terlarut mencapai konsentrasi maksimum sekitar $5,7 \mathrm{mg} / \mathrm{L}$ pada pukul 15.30 , sementara suhu mencapai puncak sekitar $29,2^{\circ} \mathrm{C}$ pada pukul 14.00. Parameter salinitas cenderung mengalami kenaikan pada awal eksperimen sekitar 32,9 psu, kemudian nilainya relatif konstan selama sekitar 13 jam dan mengalami kenaikan pada akhir eksperimen sekitar 32,95 psu.

\section{Respirasi Kerapu Macan}

Dari kegiatan eksperimen respirasi ikan yang dilakukan di labolatorium dihasilkan data yang digambarkan dalam hubungan korelasi antara laju respirasi ikan kerapu macan $\left(\mathrm{mgO}_{2} /\right.$ menit) dengan bobot badannya (g)(Gambar 3).

Hasil korelasi hubungan antara laju respirasi ikan kerapu macan dengan bobot badannya mengasilkan persamaan linier $\mathrm{Y}=$ $0,0038 \mathrm{X}+0,6108$.

\section{Perkiraan Padat Penebaran yang Optimum}

Setelah laju respirasi ikan respirasi dapat diprediksi, maka upaya memprediksi padat penebaran ikan kerapu macan dalam suatu wadah atau keramba menjadi lebih mudah. Dengan memasukkan faktor-faktor yang dapat mempengaruhi konsentrasi oksigen terlarut seperti kecepatan arus di sekitar keramba, jumlah pemasukan air yang masuk ke keramba serta perubahan suhu yang terjadi ke dalam persamaan Inoue (1974) maka didapatkan persamaan eksponensial $Y=1505,6 X^{-0.632}$ yang menggambarkan hubungan antara padat penebaran (ekor/ $\mathrm{m}^{3}$ ) dengan bobot ikan $(\mathrm{g})$.

Persamaan eksponensial pada Gambar 4 dapat menjadi rujukan bagi penentuan padat penebaran ikan kerapu macan. Untuk ikan dengan ukuran kecil (kurang dari $50 \mathrm{~g}$ ) maka padat penebaran yang disarankan adalah sekitar 175 ekor/ $\mathrm{m}^{3}$, sedangkan untuk ikan kerapu ukuran 100--200 g disarankan padat penebarannya sekitar $63 \mathrm{ekor} / \mathrm{m}^{3}$, untuk ikan kerapu ukuran induk dengan bobot di atas 1.200 g padat penebarannya sekitar 17 ekor $\mathrm{m}^{3}$.

Berikut disampaikan tabel penentuan padat penebaran berdasarkan bobot badan ikan (Tabel 2).

\section{BAHASAN}

Parameter kualitas air yang perlu mendapat perhatian dalam penentuan laju respirasi ikan adalah parameter suhu, karena suhu air akan berimbas langsung pada metabolisme respirasi

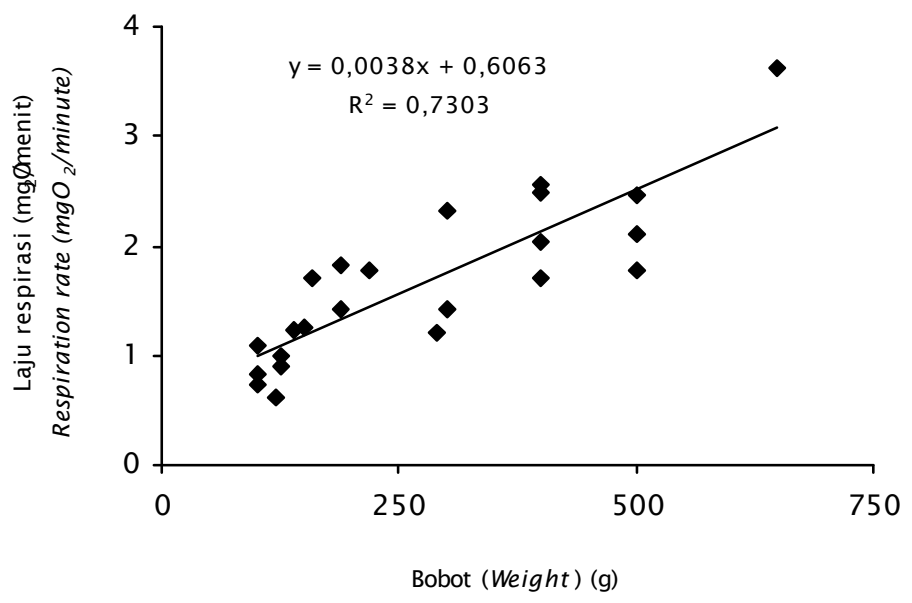

Gambar 3. Grafik hubungan antara laju respirasi ikan $\left(\mathrm{mgO}_{2} /\right.$ menit) dengan bobot tubuhnya (g)

Figure 3. Corellation graphic between fish respiration rate $\left(\mathrm{mgO}_{2} /\right.$ menit) and their weight (g) 


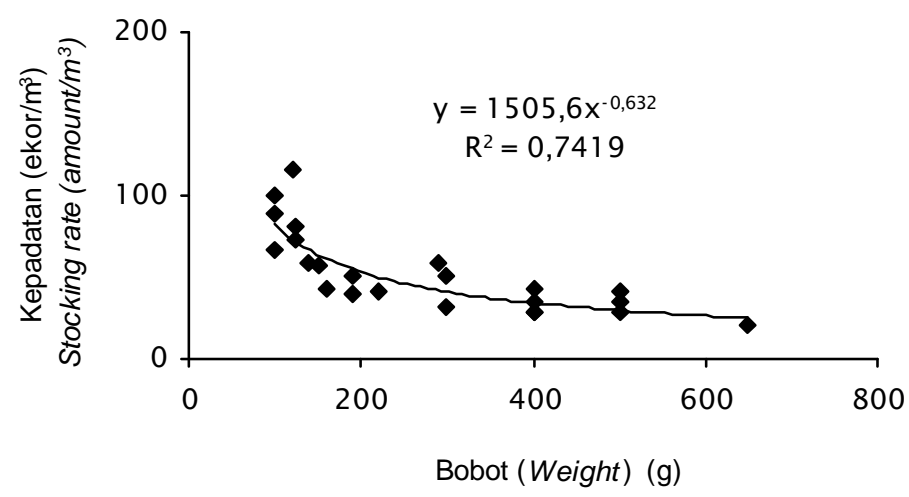

Gambar 4. Grafik hubungan antara padat penebaran $\left(\mathrm{ekor} / \mathrm{m}^{3}\right)$ dengan bobot ikan (g)

Figure 4. Corelation graphic between stocking rate (fish $\left./ \mathrm{m}^{3}\right)$ and weight $(\mathrm{g})$

Tabel 2. Daftar penentuan padat penebaran ikan kerapu macan (Epinephelus fucoguttatus)

Table 2. Stocking rate estimation list for tiger grouper (Epinephelus fuscoguttatts)

\begin{tabular}{lcccc}
\hline Bobot (Weight) $(\mathbf{g})$ & $<50$ & $\mathbf{1 0 0 - - 2 0 0}$ & $\mathbf{5 0 0 - - 6 0 0}$ & $>1,200$ \\
\hline $\begin{array}{l}\text { Kepadatan }\left(\mathrm{ekor} / \mathrm{m}^{3}\right) \\
\text { Stocking rate }\left(\mathrm{fish} / \mathrm{m}^{3}\right)\end{array}$ & 176 & 63 & 27 & 17 \\
\hline
\end{tabular}

ikan itu sendiri (Boyd, 1990; Kaspriyo et al., 2004).

Dalam penentuan padat penebaran tidak menggunakan perhitungan laju respirasi biasa : DO-respirasi $=\left(\mathrm{DO}_{\mathrm{t}}-\mathrm{DO}_{\mathrm{o}}\right) / \ddot{A} \mathrm{t}$, tetapi mengunakan formula dari Ohmori (2003):

$$
\mathrm{DO}_{\text {ikan }}=\operatorname{Ln}\left(\frac{\mathrm{DO}_{0}}{\mathrm{DO}_{1}} \Delta \mathrm{t}\right)
$$

Perhitungan DO respirasi dengan persamaan biasa menurut penulis kurang akurat karena pada persamaan tersebut tidak memperhitungkan adanya perubahan suhu selama kegiatan eksperimen berlangsung.

Untuk mengantipasi permasalahan di atas, diperlukan persamaan yang memperhitungkan adanya perubahan suhu selama eksperimen seperti yang dilakukan oleh Ohmori (2004) dalam Santoso (2005) yakni dengan membandingkan perubahan oksigen terlarut dan temperatur selama eksperimen $\left(\mathrm{DO}_{\text {fish }}\right)$ dengan perubahan oksigen terlarut dan temperatur saat kontrol ( $\left.\mathrm{DO}_{\text {control }}\right)$.
Pada Gambar 3 dapat disimpulkan bahwa dihitung per bobot badan, ikan kerapu dengan bobot kecil (kurang dari $50 \mathrm{~g}$ ) cenderung memanfaatkan oksigen lebih besar daripada ikan sejenis dengan bobot lebih besar. Hal ini bisa dipahami karena pada saat ikan berukuran kecil/muda kebutuhan oksigen untuk respirasi banyak digunakan untuk berbagai kepentingan, selain untuk metabolisme sendiri juga untuk kepentingan pertumbuhan sel, dll. Sedangkan bagi ikan dewasa tidak sebanyak seperti pada ikan kecil (Boyd, 1990).

Grafik hubungan antara laju respirasi ikan kerapu macan dengan bobot tubuhnya yang dinyatakan dalam persamaan linier $Y=0,0038 X$ $+0,6108$ (Gambar 3), menurut penulis hanya bisa diterapkan pada jenis ikan kerapu macan dan pada media dengan kisaran suhu $29,09^{\circ} \mathrm{C}$, karena pengaruh perubahan suhu memegang peranan besar pada penentuan laju respirasi ini.

Demikian pula penerapan fungsí $Y=1505,6$ $X^{-0.632}$ harus mempertimbangkan kondisi kualitas perairan dan pengaruh dari luar (pasokan air sungai). 


\section{KESIMPULAN}

Padat penebaran untuk ikan kerapu macan mengikuti persamaan eksponensial $Y=1505,6$ $\mathrm{X}^{-0.632}$. Untuk ikan berukuran kecil (kurang dari $50 \mathrm{~g}$ ) maka padat penebaran yang disarankan adalah sekitar 176 ekor/ $\mathrm{m}^{3}$, sedangkan ikan kerapu berukuran 100--200 g disarankan padat penebarannya sekitar $63 \mathrm{ekor} / \mathrm{m}^{3}$. Untuk ikan kerapu ukuran induk dengan bobot di atas $1.200 \mathrm{~g}$ padat penebarannya sekitar 17 ekor/ $\mathrm{m}^{3}$.

\section{DAFTAR PUSTAKA}

Boyd, C.F. 1990. Water quality in ponds for aquaculture. Departement of fisheries and allied aquaculture. Alabama agricultural experiment station. Auburn University, Alabama. Birmingham Publishing. 482 pp.

Fukuda, Kioushi, T. Maekawa, and Y. Kono. 1966. A study on the Shallow-Marine Cultural Facilities Hydraulics Characteristics of the Flow-Through and Tidal range Facilities and their relationship to the number fishes that can be cultivated. Technical Bulletin of faculty Agricultural. Kagawa University. 18(1): 48-53.

Inoue and Hiroo. 1974. DO Environment in Yellow tail culture farm : In Environment engineering in Agriculture and Fisheries. Memorial Publication Committee for Dr. J Sugi 6o-th Birthday. p. 298-336.
Omori, K., Y. Hayami, H. Ohnishi, N. Okuda, and H. Takeoka. 2005. Mathematical model analysis on coastal ecosystems: Sustainable usage of a coastal ecosystem. p. 5-12.

Muawanah, N. Sari, dan A.T. Kartikasari. 2003. Aspek lingkungan dalam managemen kesehatan ikan. Penanganan penyakit ikan budidaya laut. Dirjen Perikanan Budidaya Laut. DKP, Lampung. 12: 35-41.

Kaspriyo, A. Hanafi, dan D. Syahidah. 2004. Pola pemanfaatan oksigen untuk menunjang kesehatan pada ikan kerapu macan (Chromileptes altivelis) dan kerapu macan (Epinephelus fuscoguttatus). Balai Besar Riset Perikanan Budidaya Laut Gondol Bali. p. 11-16.

Nabhitabhata, J., R. Prepiyamat, K. Tharawut, and S. Kbinrum. 2002. Estimation on optimum stocking density of grouper, Epinephelus tauvina (Forskal), in cages on basis of dissolved oxygen budget: Pat-rat river. p. $130-136$.

Santoso. 2005. Laju Respirasi Ikan Kerapu. Laporan teknis tidak diterbitkan. Joint research on coastal waters environmental and fish culture at Hurun Bay Lampung. Pusat Teknologi Lingkungan, BPPT. 4 pp. 